\title{
Pengaruh Pemanfaatan Campuran Limbah Buah Durian dan Ampas Tahu Hasil Fermentasi dengan Pleurotus ostreatus dalam Ransum terhadap Performans Broiler
}

\author{
V. Y. Laoli ${ }^{*}$, Nuraini ${ }^{2}, \&$ Mirzah $^{2}$ \\ ${ }^{1}$ Program S2 Ilmu Peternakan, Fakultas Peternakan, Universitas Andalas, Padang \\ ${ }^{2}$ Program Studi Peternakan, Fakultas Peternakan, Universitas Andalas, Padang \\ Kampus Limau Manis, Kec. Pauh, Kota Padang, Sumatera Barat 25163 \\ *Email : victorpwd@yahoo.co.id
}

(Diterima : 27 Juli 2019; Disetujui : 03 Maret 2020)

\begin{abstract}
This study was conducted to determine the effect of fermented of Durian Waste and Tofu Waste (DWTW) mixture with Pleurotus ostreatus in rations on broiler performance. The material used in this study was 100 DOC broiler strain Arbor Acres (AA) CP-707. This study was designed using a completely randomized design consisting of 5 treatments and 4 replications in which each flock consisting of 5 chickens. The treatments were inclusion the levels of DWTW in rations, namely, 0, 6, 12, 18 and 24\%. The observed variables included feed consumption, body weight gain, and feed conversion ratio. The results of this study indicated that the using of DWTW in broiler ration did not significant effect $(P>0.05)$ on feed consumption, body weight gain and feed conversion ratio. In conclusion, DWTW can be utilized up to $24 \%$ in broiler rations. In this condition, average feed consumption, body weight gain, and feed conversion $57.34 \mathrm{~g} /$ chicken/day, $36.55 \mathrm{~g} /$ chicken/day and 1.57 respectively.
\end{abstract}

Keywords: broiler performance, durian waste, Pleurotus ostreatus, rations, tofu waste.

\section{PENDAHULUAN}

Bahan-bahan pakan yang berserat kasar tinggi mudah diperoleh dan biasanya harganya murah. Hal ini dapat membantu menekan biaya ransum. Serat kasar dalam ransum berfungsi positif yaitu memacu pertumbuhan organ pencernaan (Siri et al., 1992, Sutardi, 1997; Mangisah dan Nasoetion, 2006; Wahyuni et al., 2008), mencegah penggumpalan ransum dalam lambung dan usus serta membantu gerak peristaltik usus. Namun disisi lain level serat kasar yang tinggi dalam ransum sering menyebabkan kecernaan menurun (Khuzaemah, 2005) dan pemanfaatan nutrien ransum menjadi menurun serta penurunan bobot badan (Hsu et al., 2000).

Indonesia merupakan negara tropis yang dilalui garis khatulistiwa sehingga memiliki keragaman sumber daya alam yang dapat dimanfaatkan sebagai bahan makanan. Salah satu tumbuhan yang mempunyai hasil samping berlimpah adalah buah durian (Durio zibethinus). Produksi buah durian di Indonesia setiap tahunnya terus meningkat. Menurut data Direktorat Jenderal Hortikultura Kementerian Pertanian RI pada tahun 2013 produksi durian di Indonesia sebanyak 759.055 ton dan pada tahun 2017 mengalami peningkatan sebanyak 795.200 ton.
Industri pengolahan durian akan menghasilkan limbah yang banyak karena bagian yang umumnya dikonsumsi adalah daging atau salut buah yaitu 20-25\% dan sisanya adalah bagian kulit $60-70 \%$ serta biji $5-15 \%$ belum termanfaatkan secara maksimal (Untung, 2008). Kulit durian mengandung minyak atsiri, flavonoid, saponin, selulosa, lignin, serta pati. Menurut Nuraini dan Djulardi (2019), kulit durian mengandung protein kasar 4,25\%; serat kasar 29,50\% dan energi metabolisme $2.050 \mathrm{kkal} / \mathrm{kg}$. Kandungan gizi biji durian menurut Nuraini dan Mahata (1998) adalah protein kasar 9,79\%; serat kasar 2,41\% dan energi metabolisme 2.750 kkal/ $\mathrm{kg}$ dan biji durian dapat dipakai sampai pada level $24 \%$ dalam ransum broiler atau dapat menggantikan $42 \%$ jagung giling.

Guna mengatasi penurunan kecernaan dan penurunan bobot badan akibat penggunaan serat kasar yang tinggi dalam ransum maka dilakukan penelitian pengolahan biologis secara fermentasi. Pengolahan secara fermentasi memiliki keuntungan antara lain memperpanjang waktu penyimpanan, menghilangkan bau yang tidak sedap, nilai gizi lebih baik dari pada bahan asalnya, pangan hasil fermentasi lebih mudah dikonsumsi dan meningkatkan daya cerna, serta menambah flavour (Trisnadjaja dan Subroto, 1996). Proses fermentasi adalah suatu proses terjadinya 
perubahan kimia pada suatu substrat organik melalui aktivitas enzim yang dihasilkan oleh mikroorganisme (Hidayanto, 2017). Salah satu cara untuk menurunkan kandungan serat kasar, terutama selulosa dan lignin adalah dengan memanfaatkan aktivitas mikroba melalui proses biodegradasi, dimana mikroba mampu mendegradasi komponen serat secara lebih ekonomis dan hasilnya dapat lebih bermanfaat.

Salah satu bahan sumber mikroorganisme yang dapat meningkatkan protein dan menurunkan serat kasar yang pernah dilakukan oleh peneliti terdahulu adalah jamur Pleurotus ostreatus (jamur tiram) yang bersifat lignoselulolitik karena mampu mendegradasi selulosa dan lignin yang merupakan komponen dari serat kasar. Pleurotus ostreatus digolongkan white rot fungi dari kelompok Basidiomycetes yang dapat mendegradasi lignin lebih ektensif karena menghasilkan enzim ligninolitik ekstraseluler yang terdiri dari lignin peroxidase $(\mathrm{LiP})$, mangan peroxidase $(\mathrm{MnP})$ dan laccase (Hatakka, 2001) selain itu jamur Pleurotus ostreatus juga menghasilkan enzim amilase dan enzim selulase (Sudiana dan Rahmansyah, 2002) serta enzim protease (Shaba, 2012). Menurut Alarcon et al. (2003) kelebihan dari fermentasi menggunakan jamur Pleurotus ostreatus adalah dapat menghasilkan senyawa lovastatin yang dapat menghambat terbentuknya mevalonat, yang akhirnya menghambat terbentuknya kolesterol.

Laoli (2019) melaporkan limbah buah durian dan ampas tahu yang difermentasi dengan Pleurotus ostreatus dengan dosis inokulum 6\% dan lama fermentasi 9 hari mengandung protein kasar 19,25\% (terjadi peningkatan protein kasar sebesar 39,12\%), serat kasar 14,69\% (terjadi penurunan serat kasar sebesar 34,44\%). Penelitian ini bertujuan untuk mengetahui pengaruh campuran limbah buah durian dan ampas tahu yang difermentasi dengan Pleurotus ostreatus terhadap performa broiler. Penelitian ini diharapkan dapat memberikan informasi tentang penggunaan limbah buah durian dan ampas tahu yang difermentasi dengan Pleurotus ostreatus pada broiler dan level penggunaan yang tepat dalam ransum broiler.

\section{MATERI DAN METODE}

Ternak percobaan yang digunakan pada penelitian ini adalah 100 ekor broiler Day Old Chicken (DOC) strain Arbor Acres (AA) CP-707 dari PT. Charoen Phokphan Jaya Farm Medan. Penelitian ini menggunakan 5 macam ransum perlakuan yang disusun sendiri berdasarkan iso energi $2900 \mathrm{kkal} / \mathrm{kg}$ dan iso protein $21 \%$ (Leeson dan Summers, 2001). Bahan ransum yang digunakan terdiri dari : jagung giling, ransum komersial bravo 511, dedak halus, bungkil kedelai, tepung tulang, minyak kelapa, top mix serta campuran limbah buah durian dan ampas tahu yang telah difermentasi dengan Pleurotus ostreatus. Kandungan zat-zat makanan ransum penelitian dapat dilihat pada Tabel 1.

Tabel 1. Kandungan zat-zat makanan (\%) dan energi metabolisme (kkal/kg) bahan penyusun ransum (as feed) ${ }^{\mathrm{a}}$.

\begin{tabular}{|c|c|c|c|c|c|c|}
\hline Bahan Pakan & PK & LK & SK & $\mathrm{Ca}$ & $\mathrm{P}$ & ME \\
\hline Jagung giling & 8,58 & 3,77 & 2,91 & 0,38 & 0,19 & 3300,00 \\
\hline Ransum Br-511 & 21,50 & 5,00 & 5,00 & 0,90 & 0,60 & 3200,00 \\
\hline Dedak halus & 9,50 & 5,09 & 14,50 & 0,69 & 0,26 & 1630,00 \\
\hline B. kedelai & 43,43 & 2,49 & 5,50 & 0,63 & 0,36 & 2240,00 \\
\hline $\operatorname{LBDATF}^{c}$ & 17,13 & 4,78 & 13,07 & 0,32 & 0,07 & 2622,41 \\
\hline Minyak kelapa & - & 100,00 & - & - & - & 8600,00 \\
\hline Tepung tulang & - & - & - & 24,00 & 12,00 & - \\
\hline Top Mix & - & - & - & 5,38 & 1,44 & - \\
\hline
\end{tabular}

\section{Pelaksanaan Penelitian}

Pelaksanaan penelitian ini dimulai dengan mempersiapkan produk fermentasi, mempersiapkan ransum penelitian dan kandang, penempatan ayam dalam kandang, pemberian ransum perlakuan, air minum dan sanitasi kandang dan uji biologis ransum perlakuan. Pembuatan produk fermentasi terdiri dari komposisi substrat yang digunakan sebanyak 70\% limbah buah durian (75\% biji durian $+25 \%$ kulit durian) dan 30\% ampas tahu. Dosis inokulum yang digunakan adalah $8 \%$ dan level lama fermentasi adalah 9 hari. 
Langkah-langkah pelaksanaan tahap ini sebagai berikut:

- Timbang substrat dengan komposisi limbah durian dan ampas tahu yaitu 70\%:30\% sebanyak $500 \mathrm{~g}$.

- Substrat dalam kantong plastik ditambahkan $7 \mathrm{~mL}$ mineral, diaduk dalam kantong plastik sampai homogen.

- Kemudian substrat disterilisasi menggunakan autoclave (suhu $121^{\circ} \mathrm{C}$ selama 15 menit), biarkan hingga suhu turun mencapai suhu kamar, kemudian angkat dan dinginkan di dalam ruangan steril (laminar air flow).

- Substrat steril diinokulasi dengan inokulum
Pleurotus ostreatus sebayak $8 \%$ dari jumlah substrat di dalam ruangan steril (laminar air flow).

- Kemudian diinkubasi dengan lama 9 hari

- Hasil fermentasi dikeringkan pada suhu $80^{\circ} \mathrm{C}$ selama 2 jam untuk mematikan jamur, lalu dilanjutkan pengeringan pada suhu $60^{\circ} \mathrm{C}$ selama $10-12$ jam, sampai kering. Setelah itu diaduk merata, digiling dan digunakan sebagai bahan pakan campuran ransum broiler.

Masing-masing bahan pakan ditimbang menurut komposisi ransum perlakuan (Tabel 2) kemudian diaduk sampai merata.

Tabel 2. Komposisi dan kandungan nutrisi ransum perlakuan.

\begin{tabular}{lccccc}
\hline \multirow{2}{*}{ Bahan Pakan } & \multicolumn{5}{c}{ Ransum Perlakuan } \\
\cline { 2 - 6 } Jagung giling (\%) & $\mathrm{A}$ & $\mathrm{B}$ & $\mathrm{C}$ & $\mathrm{D}$ & $\mathrm{E}$ \\
Ransum Br-511 (\%) & 28,00 & 25,00 & 22,00 & 18,50 & 15,00 \\
Dedak halus (\%) & 45,00 & 45,00 & 45,00 & 45,00 & 45,00 \\
Bungkil kedelai (\%) & 4,00 & 3,00 & 2,00 & 1,00 & 0,00 \\
LBDATF (\%) & 21,00 & 19,00 & 17,00 & 15,50 & 14,00 \\
Minyak kelapa (\%) & 0,00 & 6,00 & 12,00 & 18,00 & 24,00 \\
Tepung tulang (\%) & 0,50 & 0,50 & 0,50 & 0,50 & 0,50 \\
Top Mix (\%) & 1,00 & 1,00 & 1,00 & 1,00 & 1,00 \\
\hline Total & 0,50 & 0,50 & 0,50 & 0,50 & 0,50 \\
\hline Kandungan Nutrisi & 100,00 & 100,00 & 100,00 & 100,00 & 100,00 \\
\hline PK (\%) & 21,58 & 21,38 & 21,19 & 21,17 & 21,15 \\
Lemak (\%) & 4,53 & 4,61 & 4,68 & 4,74 & 4,81 \\
SK (\%) & 4,80 & 5,24 & 5,68 & 6,14 & 6,59 \\
Ca (\%) & 0,94 & 0,93 & 0,91 & 0,90 & 0,89 \\
P(\%) & 0,54 & 0,52 & 0,51 & 0,50 & 0,49 \\
ME (kkal/kg) & 2942,60 & 2939,84 & 2937,09 & 2937,09 & 2920,98 \\
\hline
\end{tabular}

Kandang dibersihkan, dikapuri dan disemprot dengan rodalon, demikian juga halnya dengan tempat pakan dan minum dibersihkan dan disterilisasi dengan menggunakan air panas. Setiap unit kandang diberi lampu pijar $60 \mathrm{watt}$, tempat pakan dan tempat minum.

Penempatan ayam dalam kandang dilakuan dengan cara menimbang sepuluh anak ayam terlebih dahulu dan dicari bobot rata-rata untuk dijadikan bobot patokan, lalu diambil 2 level di atas bobot rata-rata dan 2 level di bawah bobot rata-rata. Sediakan 5 kotak untuk menempatkan anak ayam sesuai dengan bobot badannya. Anak ayam ditimbang dan dimasukkan ke dalam unit-unit kandang yang telah diberi nomor 1-20 secara bolakbalik. Anak ayam diambil dan diletakkan pada kandang dari berat badan terendah sampai berat badan tertinggi. Setiap unit kandang berisi 5 ekor anak ayam, sedangkan untuk kode perlakuan diletakkan secara acak pada setiap unit kandang. Setiap ayam dalam satu unit kandang diberi kode cat pada kepala, sayap kanan, sayap kiri, ekor dan polos. Penempatan perlakuan menggunakan sistem lotre dengan membuat huruf A-E. Perlakuan dimulai dari minggu ke-1 sampai minggu ke-4.

Ransum dan air minum diberikan 2 kali sehari yaitu pagi dan sore secara terus menerus (adlibitum), dalam air minum ayam diberi vitastress sebagai antibiotik untuk mencegah 
stress. Setiap pagi alas kandang berupa koran diganti sampai umur 1 minggu, litter kandang tetap diperhatikan kelembapannya, dan tempat makan dan minum dibersihkan per hari. Penimbangan dilakukan setiap minggu. Sisa ransum dikumpulkan per hari dan ditimbang sekali seminggu.

\section{Peubah yang Diamati}

1. Konsumsi ransum (g/ekor/hari)

Konsumsi ransum (g/ekor/hari) merupakan selisih dari jumlah ransum yang diberikan dengan jumlah sisa ransum di akhir minggu dibagi 7 hari atau bisa juga di sebut angka yang menunjukan rata-rata jumlah pakan yang konsumsi seekor ayam sesuai dengan periode pemeliharaan (g/ekor/hari) (Scott et al., 1982).

Nilai konsumsi ransum didapatkan dengan menggunakan perhitungan : Konsumsi ransum $(\mathrm{g} /$ ekor $/$ hari $)$ = ransum yang diberikan - ransum sisa dibagi dengan jumlah hari selama penelitian.

\section{Pertambahan bobot badan (g/ekor/hari)}

Pertambahan bobot badan g/ekor/hari adalah selisih antar bobot badan akhir minggu sebelumnya dengan bobot badan awal minggu sebelumnya dibagi 7 hari (g/ekor/hari) (Rasyaf, 2004).

\section{Konversi ransum}

Konversi ransum merupakan perbandingan antara konsumsi ransum dengan pertambahan bobot badan (Jull, 1982). Nilai konversi ransum didapatkan dengan menggunakan perhitungan : Konversi ransum = Konsumsi pakan (g/ekor/hari) / PBB (g/ ekor/hari).

\section{Rancangan Percobaan}

Percobaan ini menggunakan Rancangan Acak Lengkap (RAL) dengan 5 perlakuan ransum dan 4 ulangan. Perlakuan A $(0 \%$ LBDATF dalam ransum), Perlakuan B $(6 \%$ LBDATF dalam ransum), Perlakuan C (12\% LBDATF dalam ransum), Perlakuan D (18\% LBDATF dalam ransum) dan Perlakuan E (24\% LBDATF dalam ransum). Susunan ransum perlakuan, kandungan gizi dan energi metabolismenya dapat dilihat pada Tabel 2. Model matematis yang digunakan adalah menurut Steel dan Torrie (1991). Data yang diperoleh dianalisa dengan ANOVA, jika terdapat pengaruh terhadap peubah yang diukur, maka akan dilanjutkan dengan uji DMRT.

\section{HASIL DAN PEMBAHASAN}

\section{Pengaruh Pemberian Ransum yang Mengandung LBDATF dengan Pleurotus ostreatus terhadap Konsumsi Ransum (g/ ekor/hari)}

Rataan konsumsi ransum broiler yang mengandung LBDATF dengan Pleurotus ostreatus dapat dilihat pada Gambar 1.

Hasil analisis keragaman menunjukkan penggunaan campuran limbah buah durian dan ampas tahu yang difermentasi (LBDATF) dengan Pleurotus ostreatus memberikan pengaruh berbeda tidak nyata $(\mathrm{P}>0,05)$ terhadap konsumsi ransum broiler. Berbeda tidak nyatanya konsumsi ransum broiler dengan penggunaan LBDATF sampai level $24 \%$ dalam ransum disebabkan oleh palatabilitas (tingkat kesukaan) yang sama pada perlakuan A (0\% LBDATF) walaupun terjadi pengurangan penggunaan jagung dan bungkil kedelai sampai dengan perlakuan E (24\% LBDATF). Dari hasil penelitian, terlihat bahwa penggunaan sampai $24 \%$ LBDATF dengan Pleurotus ostreatus dalam ransum dapat menurunkan penggunaan jagung sebesar $53,57 \%$ dan menurunkan penggunaan bungkil kedelai sebesar $66,67 \%$. Ini jumlah yang cukup signifikan untuk menurunkan harga ransum yang berikan.

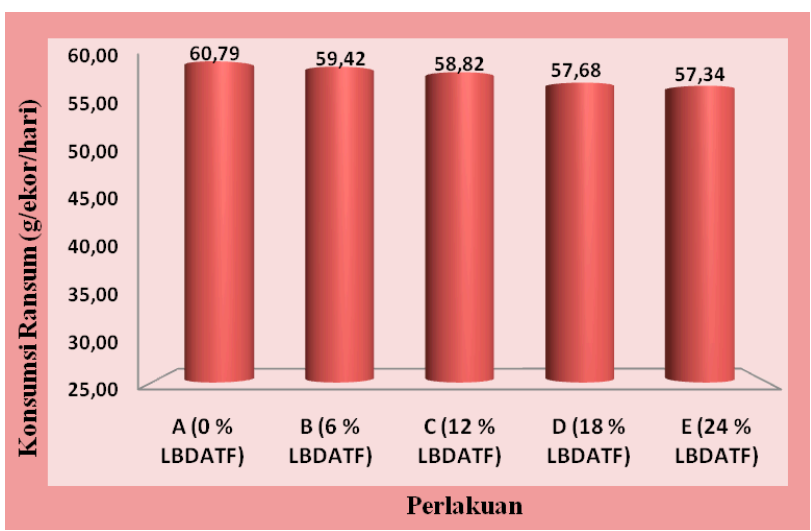

Keterangan : ns : berbeda tidak nyata $(\mathrm{P}>0,05)$ SE : Standard error $(1,128)$.

Gambar 1. Rataan konsumsi ransum broiler (g/ekor/hari).

Menurut Pond et al. (1995) konsumsi ransum juga dipengaruhi oleh palatabilitas ransum, dimana palatabilitas didefinisikan sebagai daya tarik suatu pakan atau bahan pakan untuk menimbulkan selera makan dan dimakan oleh ternak, sebab palatabilitas ditentukan oleh rasa, bau dan warna. Limbah durian merupakan limbah agroindustri yang 
mengandung serat kasar yang tinggi, namun setelah difermentasi dengan Pleurotus ostreatus terjadi penurunan serat kasar, peningkatan protein dan meningkatkan palatabilitas, sehingga penggunaan produk LBDATF dapat meningkat sebagai ransum bagi ternak. Hal ini sesuai dengan pendapat Murugesan et al. (2005) bahwa produk fermentasi mempunyai flavour yang lebih disukai dan memiliki beberapa vitamin (B1,B2 dan B12) sehingga lebih disukai bila dibandingkan dengan bahan asalnya. Selain itu pada fermentasi terjadi prosesproses pemecahan oleh enzim-enzim tertentu terhadap nutrien yang sulit dicerna, sehingga daya cerna bahan yang telah difermentasi meningkat dibandingkan bahan asalnya.

Produk fermentasi itu sendiri memberikan pengaruh fisik terhadap limbah durian yang awalnya berwarna gelap sebelum fermentasi menjadi terang setelah fermentasi, ditambah oleh warna terang dan cerah yang berasal dari banyaknya penggunaan jagung dalam ransum. Konsumsi ransum yang sama menyebabkan warna ransum pada perlakuan A $(0 \%$ LBDATF) sampai ransum pada perlakuan $\mathrm{E}$ (24\% LBDATF) juga sama, sehingga disukai ternak. Rasyaf (2004) menyatakan ternak lebih menyukai ransum yang berwarna cerah dan terang.

Ichwan (2003) menyatakan faktor-faktor yang memengaruhi konsumsi pakan pada unggas adalah kandungan serat kasar dalam pakan, tingkat kualitas pakan, palatabilitas dan cita rasa pakan. Ayam tidak dapat memanfaatkan serat kasar sebagai sumber energi. Serat kasar ini dibutuhkan dalam jumlah kecil oleh unggas yang berperan sebagai bulky, yaitu untuk memperlancar pengeluran feses (Rizal, 2006). Jika dilihat pada tabel kandungan nutrisi ransum perlakuan (Tabel 2), maka kandungan serat kasar pada ransum A sampai ransum E sebesar 4,8\%-6,59\% (masih berada dalam nilai normal), sehingga tidak memberikan pengaruh terhadap konsumsi ransum broiler.

Konsumsi ransum broiler yang diperoleh selama penelitian pada perlakuan $\mathrm{E}$ adalah 57,34 g/ekor/hari. Angka ini lebih tinggi dari konsumsi ransum broiler menurut Nuraini dan Djulardi (2019) yaitu 56,82 g/ekor/hari dengan pengunaan campuran limbah buah durian dan ampas tahu fermentasi dengan Phanerochaete crhysosporium dan Neurospora crassa.
Pengaruh Pemberian Ransum yang Mengandung LBDATF dengan Pleurotus ostreatus terhadap Pertambahan Bobot Badan (g/ekor/hari)

Rataan pertambahan bobot badan broiler yang diperoleh selama penelitian dapat dilihat pada Gambar 2.

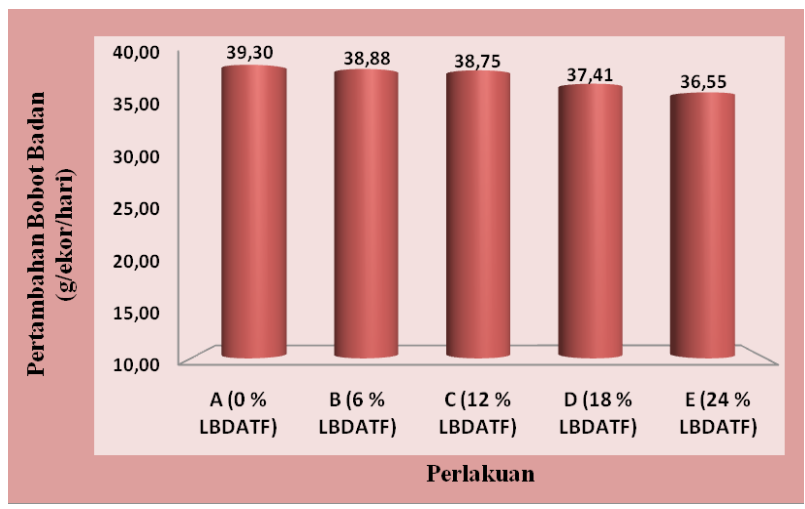

Keterangan : ns : berbeda tidak nyata $(\mathrm{P}>0,05)$ SE : Standard error $(0,74)$

Gambar 2. Rataan pertambahan bobot badan (g/ekor/hari).

Pertambahan bobot badan broiler pada masing-masing perlakuan selama penelitian dari perlakuan A (0\% LBDATF) sampai E (24\% LBDATF) berkisar 36,55-39,30 g/ekor/ hari. Hasil analisis keragaman menunjukkan penggunaan campuran limbah buah durian dan ampas tahu yang difermentasi (LBDATF) dengan Pleurotus ostreatus memberikan pengaruh berbeda tidak nyata $(\mathrm{P}>0,05)$ terhadap pertambahan bobot badan broiler.

Berbeda tidak nyatanya pengaruh perlakuan terhadap pertambahan bobot badan dengan pemberian produk LBDATF dengan Pleurotus ostreatus sampai level 24\% dalam ransum disebabkan jumlah ransum yang dikonsumsi broiler pada masing-masing perlakuan juga sama. Konsumsi ransum yang sama mengakibatkan jumlah zat-zat makanan yang termanfaatkan untuk pembentukan jaringan tubuh sama, sehingga pertambahan bobot badan yang dihasilkan juga seragam. Menurut Wahju (1997) bahwa konsumsi ransum yang sama akan menghasilkan bobot hidup yang sama.

Jika diperhatikan secara angka-angka pada Gambar 2, rataan pertambahan bobot badan cenderung menurun dari perlakuan A sampai perlakuan E. Penurunan bobot badan broiler ini disebabkan karena kandungan serat kasar pada ransum penelitian berbanding terbalik (semakin naik) dari perlakuan A sampai perlakuan $\mathrm{E}$ 
sebesar 4,8\%-6,59\% (Tabel 2), namun masih berada dalam nilai normal sehingga tidak memberikan pengaruh yang nyata terhadap konsumsi ransum dan pertambahan bobot badan broiler. Wahyu (1997) menyatakan serat kasar yang tidak tercerna dapat membawa nutrien lain keluar dari tubuh bersama kotoran. Serat yang terlalu banyak dalam tubuh ayam akan berdampak buruk karena serat akan menyerap air, menyerap asam-asam empedu dan asam-asam amino menuju keluar tubuh dalam bentuk feses, akibatnya ayam kurang memperoleh asupan gizi yang cukup untuk proses pembentukan sel-sel dan jaringan tubuh pembentuk daging, sehingga terjadi penurunan terhadap pertambahan bobot badan. Rizal (2006) menambahkan jika kandungan serat kasar tinggi dalam pakan, maka saluran pencernaan ayam akan cepat merasa kenyang, karena serat bersifat voluminous.

\section{Laelasari dan Purwadaria}

menyatakan bahan yang mengalami fermentasi kualitasnya akan lebih baik. Secara umum semua produk akhir fermentasi biasanya mengandung senyawa yang lebih sederhana dan mudah dicerna dari pada bahan asalnya, sehingga konsumsi ransum yang sama dikarenakan terjadinya fermentasi LBDAT dengan Pleurotus ostreatus dapat menyebabkan pemecahan kandungan zat makanan yang kompleks yaitu protein, lemak dan karbohidrat menjadi lebih sederhana sehingga meningkatkan nilai gizinya.

Rasyaf (2004) menyatakan fungsi produksi ayam broiler merupakan hubungan antara kandungan protein ransum dengan pertambahanbobotbadan ayam broiler tersebut. Pada tingkat protein yang rendah dalam ransum, ayam broiler akan memberikan respon pertambahan bobot badan yang rendah juga. Tingkat protein yang baik dalam ransum, ayam broiler akan memberikan respon pertambahan bobot badan yang baik juga, sehingga pertambahan bobot badan dipengaruhi oleh jumlah ransum yang dikonsumsi dan kualitas protein ransum. Samanya pertambahan bobot badan dari perlakuan A (0\% LBDATF) sampai perlakuan E (24\% LBDATF) menunjukkan kualitas protein ransum sama dari perlakuan A, B, C, D dan E.

Pertambahan bobot badan broiler yang diperoleh selama penelitian pada perlakuan $\mathrm{E}$ adalah 36,55 g/ekor/hari. Angka ini lebih ini lebih tinggi dari pertambahan bobot badan broiler menurut Nuraini dan Djulardi (2019) yaitu 30,39 g/ekor/hari dengan pengunaan campuran limbah buah durian dan ampas tahu fermentasi dengan Phanerochaete crhysosporium dan Neurospora crassa.

\section{Pengaruh Perlakuan terhadap Konversi Ransum}

Rataan konversi ransum broiler yang diperoleh selama penelitian dapat dilihat pada Gambar 3.

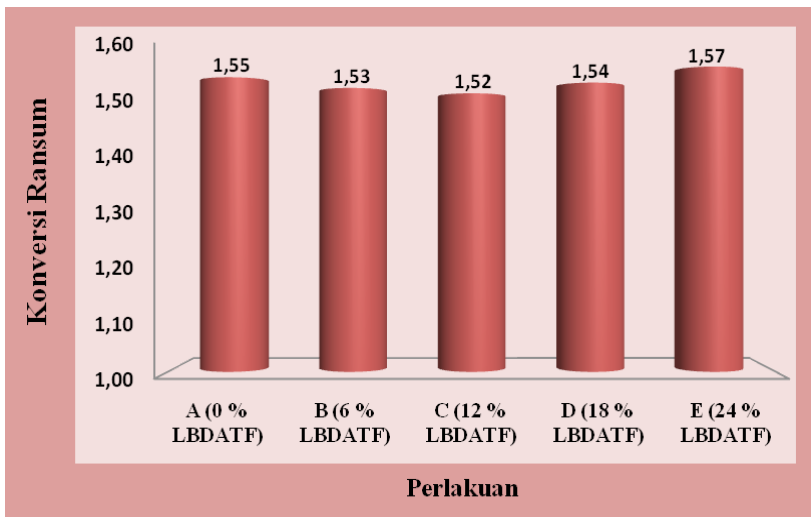

Keterangan : ns : berbeda tidak nyata $(\mathrm{P}>0,05)$ SE : Standard error $(0,03)$

Gambar 3. Rataan konversi ransum.

Hasil analisis keragaman menunjukkan penggunaan campuran limbah buah durian dan ampas tahu yang difermentasi (LBDATF) dengan Pleurotus ostreatus memberikan pengaruh berbeda tidak nyata $(\mathrm{P}>0,05)$ terhadap konversi ransum broiler.

Konversi ransum yang sama berkaitan dengan konsumsi ransum dan pertambahan bobot badan broiler yang masing-masing juga seragam dipengaruhi oleh perlakuan, karena konversi ransum diperoleh dari perbandingan ransum yang dikonsumsi dengan pertambahan bobot badan dalam waktu tertentu. Nilai konversi ransum ditentukan oleh banyaknya konsumsi ransum dan pertambahan bobot badan yang dihasilkan. Jadi dengan konsumsi ransum yang sama yang diikuti dengan pertambahan bobot badan yang seragam akan menghasilkan konversi ransum yang tidak berbeda.

Tinggi rendahnya nilai konversi ransum sangat dipengaruhi oleh konsumsi ransum dan pertambahan bobot badan harian (Rasyaf, 2011 dan Zahra et al., 2012). Amrullah (2003) menambahkan semakin baik kualitas ransum, semakin kecil pula nilai konversi ransumnya. Baik tidaknya kualitas ransum, ditentukan oleh keseimbangan nutrien dalam ransum itu yang diperlukan oleh ternak. Ransum yang bermutu baik dengan kandungan gizi yang seimbang dan mempunyai palatabilitas yang tinggi menghasilkan konversi ransum yang semakin 
baik, sebaliknya ransum yang bermutu rendah dengan palatabilitas yang rendah menghasilkan konversi yang rendah. Semakin kecil konversi ransum berarti pemberian ransum semakin efisien, namun jika konversi ransum tersebut membesar maka terjadi pemborosan. Mahfudz (2004) menyatakan adanya peningkatan efisiensi penggunaan ransum yang mengandung bahan pakan hasil fermentasi pada ayam pedaging.

Konversi ransum broiler yang diperoleh selama penelitian pada perlakuan E adalah 1,57. Angka ini lebih ini lebih rendah (lebih baik) dari konversi ransum broiler menurut Nuraini dan Djulardi (2019) yaitu 1,87 dengan pengunaan campuran limbah buah durian dan ampas tahu fermentasi dengan Phanerochaete crhysosporium dan Neurospora crassa dimana perlakuan E sendiri telah mengurangi penggunaan jagung sebesar 53,57\% dan bungkil kedelai sebesar $66,67 \%$ dalam ransum yang diberikan.

\section{KESIMPULAN}

Pemberian produk fermentasi limbah buah durian menggunakan Pleurotus ostreatus hingga level $24 \%$ dalam ransum dapat mempertahankan performa broiler. Pada kondisi ini diperoleh konsumsi ransum 57,34 gr/ekor/hari, pertambahan bobot badan 36,55 gr/ekor/hari dan konversi ransum 1,57 dan pemberian sampai level $24 \%$ dalam ransum broiler dapat menurunkan penggunaan jagung sebesar 53,57\% dan bungkil kedelai sebesar $66,67 \%$.

\section{DAFTAR PUSTAKA}

Alarcon, J., S. Aquila, P. A Avila, O. Fuentes, E. Z Ponce, \& M. Hernandes. 2003. Production and purification of sttins from Pleurotus ostreatus (Basidiomycetes) strains. Z. Naturforsh. 58 : 62-68.

Amrullah, I. K. 2003. Nutrisi Ayam Broiler. Cetakan Pertama. Lembaga Satu Gunung Budi. Bogor.

Direktorat Jenderal Hortikultura. 2017. Produksi durian menurut Provinsi 2013-2017. http//:www.pertanian.go.id/Data5tahun/ HortiATAP2017(.pdf)/Produksi\%20Durian. pdf. Diakses tanggal 14 Februari 2019.

Hatakka, A. 2001.Biodegradation of lignin. In: Steinbuchel A. [ed] Biopolymers. Vol 1: Lignin, Humic Substances and Coal. Germany: Wiley VCH., pp. 129-180.

Hidayanto, A. P. 2017. Modul Mata Kuliah Teknologi Fermentasi. Program Studi Bioteknologi. Universitas Esa Unggul. Jakarta.
Hsu, J. C., L. I.Chen, \& B. Yu. 2000. Effect of levels of crude fiber on growth performances and intestinal carbohydrase of domestic gosling. Asian-Aust. J. Anim. Sci. 13(10) : 1450-1455.

Ichwan, 2003. Membuat Pakan Ras Pedaging. Agro Media Pustaka. Tangerang.

Jull, M. A. 1982. Poultry Husbandry. Third Edition. Mc Graw Hill Book Company, Inc. New York.

Khuzaemah, S. 2005. Pengaruh Aras Serat Kasar Ransum terhadap Kecernaan Serat kasar, Protein Kasar dan Energi Metabolis pada Itik Tegal Jantan. Skripsi. Fakultas Peternakan Universitas Diponegoro, Semarang.

Laelasari. \& T. Purwadaria. 2004. Pengkajian nilai gizi hasil fermentasi mutan Aspergillus niger pada substrat bungkil kelapa dan bungkil inti sawit. Biodiversitas. 5(2) : 48-51.

Laoli, V. Y. 2019. Peningkatan Kualitas Campuran Limbah Buah Durian dan Ampas Tahu Fermentasi dengan Pleurotus ostreatus dan Aplikasinya dalam Ransum Broiler. Tesis. Pascasarjana Fakultas Peternakan. Universitas Andalas, Padang

Leeson, S. \& J. D. Summers. 2001. Nutrition of The Chicken. 4th Ed. University Books. Guelph, Ontario, Canada.

Mahfudz, L. D., W. Sarengat, D. S. Prayitno, \& U. Atmomarsono. 2004. Ampas tahu yang difermentasi dengan laru oncom sebagai pakan ayam ras pedaging. Dalam: Seminar Nasional Kebangkitan Teknologi Peternakan dan Veteriner. Fakultas Peternakan. Universitas Diponegoro. hal. 479-485.

Mangisah, I. \& M. H. Nasoetion. 2006. Peranan dan Pengaruh Serat Kasar terhadap Ukuran Sekum, Produksi dan Absorbsi Volatile Fatty Acid (VFA) pada Pemberdayaan Peternakan Berbasis Sumber Daya Lokal untuk Ketahanan Pangan Nasional Berkelanjutan 693 Itik Tegal. Laporan Penelitian Dosen Muda. Fakultas Peternakan Universitas Diponegoro, Semarang.

Murugesan, G. S., M. Sathishkumar, \& K. Swarninathan. 2005. Suplementation of waste tea fungal biomass as a dietary ingredient for broiler chiken. Bioresource Technology 96 : 1743-1748.

Nuraini \& A. Djulardi. 2019. Peningkatan Kualitas Limbah Buah Durian melalui Fermentasi untuk Unggas. Buku (unpublised).

Nuraini \& M. E. Mahata. 1998. Pemanfaatan biji durian (Durio zibethinus) sebagai pengganti jagung dalam ransum broiler. Lembaga Penelitian. Universitas Andalas. Padang.

Pond, W. G. D. C. Church, \& K. R. Pond. 1995. Basic animal nutrition and feeding $4^{\text {th }} \mathrm{ed}$. Jhon Wiley.And Soninc, Canada.

Rasyaf, M. 2004. Beternak Ayam Pedaging. Penebar Swadaya, Jakarta.

Rasyaf, M. 2011. Panduan Beternak Ayam Pedaging. Cetakan ke-4. Penebar Swadaya. Jakarta 
Rizal, Y. 2006. Ilmu Nutrisi Unggas. Andalas University Press. Padang.

Scott, M. L., M. C. Nasheim, \& R. J. Young. 1982. Nutrition of The Chicken 3rd Ed. Publishing. M. C. Scott and Associates. Ithaca, New York.

Shaba., A. M. \& J. Baba. 2012. Screening of Pleurotus ostreatus and Gleophylum septarium strain for extracellular protease enzim production. Bayero Journal of Pure and Applied Science. $5: 1$.

Siri, S., H. Tabioka, \& I. Tasaki. 1992. Effect of dietary fibre on utilization of energy and protein in chickens. Poult. Sci. J. 29 : 23-28.

Steel, R. G. \& J. H. Torrie. 1991. Prinsip dan Prosedur Statistika Suatu Pendekatan Biometrik. Ed 2 cet 2, Alih Bahasa oleh Bambang Sumantri. Gramedia Pustaka Utama. Jakarta.

Sudiana, I. M. \& M. Rahmansyah. 2002. Aktivitas amilase dan selulase jamur tiram putih yang ditumbuhkan pada medium ampas aren dan serbuk gergaji kayu. Jurnal Mikrobiologi Indonesia, $7: 7-10$.

Sutardi, T. 1997. Peluang dan Tantangan Pengembangan Ilmu-ilmu Nutrisi Ternak. Orasi Ilmiah Guru Besar Tetap Ilmu Nutrisi Ternak, Fakultas Peternakan Institut Pertanian Bogor, Bogor.
Trisnadjaya, D. \& M. A. Subroto. 1996. Analisis ekonomi untuk komersialisasi proses fermentasi. Warta Biotek. 10(3) : 1-12.

Untung, O. 2008. Durian untuk Kebun Komersial dan Hobi. Penebar Swadaya. Jakarta.

Wahju, J. 1997. Ilmu Nutrisi Unggas. Cetakan ke-4. Gajah Mada University Press. Yogyakarta.

Wahyuni, H. I., I. Mangisah., \& N. Suthama. 2008. Pengaruh Pakan Berserat Tinggi dan Probiotik dalam Ransum terhadap Pertumbuhan Organ Pencernaan, Kecernaan Ransum dan Kinerja Itik. Laporan Penelitian Kegiatan A3 Jurusan Nutrisi dan Makanan Ternak. Fakultas Peternakan Universitas Diponegoro, Semarang.

Zahra, A. A., D. Sunarti, \& E. Suprijatna. 2012. Pengaruh pemberian pakan bebas pilih (Free choice feeding) terhadap performans produksi telur burung puyuh (Coturnix coturnix japonica). Animal Agricultural Journal. 1 : 1 11. 